\title{
Improved Image Quality and Detectability of Hypovascular Liver Metastases on DECT with Different Adjusted Window Settings
}

\author{
Verbesserte Bildqualität und Nachweisbarkeit von \\ hypovaskularisierten Lebermetastasen im DECT mit \\ angepassten Fensterwerteinstellungen
}

Authors

Jens Altenbernd, Michael Forsting, Thomas Lauenstein, Axel Wetter

\section{Affiliation}

Department of Diagnostic and Interventional Radiology and Neuroradiology, University Duisburg-Essen, Medical Faculty, Essen, Germany

Key words

image manipulation/reconstruction, liver, dual energy $C T$, metastases, window setting

received 8.1.2016

accepted 6.8.2016

Bibliography

DOI http://dx.doi.org/10.1055/s-0042-115571

Published online: 21.12.2016 | Fortschr Röntgenstr 2017; 189: 228231

(c) Georg Thieme Verlag KG Stuttgart · New York ISSN 1438-9029

\section{Correspondence}

Dr. Jens Altenbernd

Klinik für Radiologie, Neuroradiologie und Nuklearmedizin, Klinikum Vest,

Dorstenerstr. 151

45657 Recklinghausen

\section{Germany}

Tel.: ++ 49/2361/5683825

Fax: $++49 / 2461 / 563898$

jens.altenbernd@gmail.com

\section{ZUSAMMENFASSUNG}

Ziel Untersuchung der Dual-Energy-Computertomografie (DECT) von hypovaskularisierten Lebermetastasen (LM) unter Berücksichtigung der Fensterwerteinstellungen (WS). Ziel der Studie ist zu untersuchen, inwiefern angepasster WS sowie die Niedrig-Energie-Datensätze der DECT die Erkennbarkeit insbesondere kleiner LM verbessern.

Material und Methoden 30 Patienten mit Lebermetastasen eines kolorektalen Karzinoms wurden mit einer DECT der Leber in portalvenöser Kontrastierung untersucht. Die Gesamtanzahl, durchschnittliche Anzahl und Erkennbarkeit ( $1=$ exzellent $-5=$ nicht beurteilbar) der LM wurden ausgewertet in $80 \mathrm{kV}$ und virtuellen $120 \mathrm{kV}$ Bilddaten mit verschiedenen Fensterwerteinstellungen (25/200 HU, 50/200 HU, 75/200 HU, 25/350 HU, 50/350 HU, 75/350 HU, 25/500 HU, 50/ $500 \mathrm{HU}, 75 / 500 \mathrm{HU})$. Die CT-Dichte (HU) der LM und weiterer anatomischer Regionen sowie das Bildrauschen der $80 \mathrm{kV}$ - und virtuellen
120 kV-Bilder wurden bestimmt. Die Quotienten Signal/Bildrauschen (SNR) und Leber/LM (LLMR) wurden berechnet. Die Gesamtanzahl der LM abhängig von der Größe $(<1 \mathrm{~cm}, 1-2 \mathrm{~cm},>2 \mathrm{~cm})$ wurden jeweils für die $80 \mathrm{kV}$ - und virtuellen $120 \mathrm{kV}$-Bilddaten - bestimmt. Hierfür wurden reguläre und zuvor ermittelte optimierte Fensterwerteinstellungen verwendet.

Ergebnisse Die höchste Gesamtanzahl, durchschnittliche Anzahl und Gesamtanzahl von $\mathrm{LM}<1 \mathrm{~cm}$ wurden mit WS $25 / 350 \mathrm{HU}$ und $80 \mathrm{kV}$ Bildern $(7,0 ; p=0,02 / 218 ; p=0,01 / 64 ; p<0,001)$ verglichen mit WS $75 / 200 \mathrm{HU}$ und virtuellen $120 \mathrm{kV}$-Bildern sowie regulären WS 50/ $350 \mathrm{HU}$ und $80 \mathrm{kV}$ und virtuellen $120 \mathrm{kV}$-Bildern. Die beste Erkennbarkeit wurde für WS 25/350 HU mit $80 \mathrm{kV}$-Bildern verglichen mit WS 75/ $200 \mathrm{HU}$ und virtuellen $120 \mathrm{kV}(1,2$ vs. 2,$5 ; \mathrm{p}=0,01)$. Die $\mathrm{HU}$ des normalen Lebergewebes, der Aorta, die SNR und LLMR unterschieden sich signifikant zwischen den $80 \mathrm{kV}$ - und virtuellen $120 \mathrm{kV}$ Bilddaten (128 HU vs. $93 \mathrm{HU},<0,05 / 192 \mathrm{HU}$ vs. $131 \mathrm{HU},<0,05 / 10,3$ vs. 8,1 ; $\mathrm{p}<0,05 / 2,8$ vs. 2,$1 ; \mathrm{p}<0,05)$.

Schlussfolgerung $80 \mathrm{kV}$-Bilddaten der DECT sind genauer bezüglich der Erkennbarkeit hypovaskularisierter Lebermetastasen im Vergleich zu virtuellen $120 \mathrm{kV}$-Bilddaten. Optimierte Fensterwerteinstellungen führen zusätzlich zu einer verbesserten Detektion.

\section{Kernaussagen:}

- Die DECT ist eine vielversprechende Methode zur Detektion hypovaskularisierter Lebermetastasen.

- Die Genauigkeit der 80 kV Bilddaten wird durch optimierte Fensterwerteinstellungen erhöht.

- Die Verwendung alleiniger Niedrig-kV-Bilddaten würde zu einer verminderten Strahlenexposition führen.

\section{ABSTRACT}

Objective To investigate dual-energy CT of hypovascular liver metastases (LMs) with special focus on window settings (WSs). The aim of the study is to investigate the extent to which adapted WSs and the low-energy images of DECT improve the visibility especially of smaller LMs.

Materials and Methods 30 patients with LMs of colorectal cancer were investigated with DECT of the liver. In each patient contrast-enhanced DECT imaging with portal-venous delay was performed. The total number, mean number and conspicuity ( $1=$ excellent $-5=$ poor $)$ of LMs were documented on $80-\mathrm{kVp}$ images and virtual $120-\mathrm{kVp}$ images with different WSs (25/200 HU, 50/200, 75/200 HU, 25/350 HU, 50/350 HU, 75/350 HU, 25/500 HU, 50/500 HU, 75/500 HU). The attenuation $(\mathrm{HU})$ of $\mathrm{LMs}$ and several anatomic regions and the background noise on $80 \mathrm{kVp}$ images and virtual $120 \mathrm{kVp}$ images were documented. Signal (liver)/noise and liver/LM ratio (SNR/LLMR) were calculated. The total number of LMs depending on size $(<1 \mathrm{~cm}, 1-$ 
$2 \mathrm{~cm},>2 \mathrm{~cm}$ ) on $80 \mathrm{kVp}$ images and virtual $120 \mathrm{kVp}$ images with previously investigated best and regular WSs were documented.

Results The highest total number, mean number per patient and total number of LMs $<1 \mathrm{~cm}$ were detected with the WS 25/350 HU on $80 \mathrm{kVp}$ images (7.0; $p=0.02 / 218 ; p=0.01 / 64 ; p<0.001)$ compared to the WS $75 / 200 \mathrm{HU}$ on virtual $120 \mathrm{kVp}$ images and the regular WS 50/350 HU on $80 \mathrm{kVp}$ images and virtual $120 \mathrm{kVp}$ images. The best conspicuity of LMs on $80 \mathrm{kVp}$ images was documented with the WS 25/350 HU compared to the best WS on virtual $120 \mathrm{kVp}$ images with 75/200 HU (1.2 vs. 2.5; $\mathrm{p}=0.01)$. HU of normal liver, aorta, SNR and LLMR differed significantly between $80 \mathrm{kVp}$ images and virtual $120 \mathrm{kVp}$ images (128.1 vs. 93.6; $<0.05 / 192.8$ vs. $131.4 ;<0.05 / 10.3$ vs. $8.1 ; p<0.05 / 2.8$ vs. $2.1 ; p<0.05$ ). Conclusion Low kVp images of DECT datasets are more precise in detecting hypovascular liver metastases than virtual $120 \mathrm{kVp}$ images. Dedicated window settings have a relevant influence on conspicuity.
Key points:

- DECT is a promising tool for detecting hypovascular liver metastases.

- The diagnostic value of low kVp image data can be significantly increased by using special window settings.

- Use of only the low kVp images would lead to reduced radiation exposure.

\section{Citation Format}

- Altenbernd Jens, Forsting Michael, Lauenstein Thomas et al. Improved Image Quality and Detectability of Hypovascular Liver Metastases on DECT with Different Adjusted Window Settings. Fortschr Röntgenstr 2017; 189: 228-231

\section{Introduction}

Several studies have demonstrated the benefits of dual-energy CT for the detection of hypervascular abdominal lesions, especially of the liver [1 -4]. The value of dual-energy CT for contrast-enhanced abdominal organ imaging is an exciting topic. The improved CT contrast resolution obtained at low $k \mathrm{~V}$ settings has been shown to provide higher detection rates of hypervascular lesions in phantom and clinical hepatic imaging, provided that the noise in the low $k V p$ image is not excessive [4, 5]. Further attention should be paid to the visibility of hypodense hepatic metastases [6-9]. $80 \mathrm{kVp}$ data acquired from a DECT scanner demonstrate a greater attenuation difference between metastatic disease and normal liver, thus increasing lesion conspicuity and potentially improving assessment of early metastatic disease [9].

It is unclear whether window settings (WSs) can influence the performance of low kVp images. While liver windows (50/ $350 \mathrm{HU}$ ) are commonly used in clinical practice, a study concluded that the use of liver windows has limited added value in the detection of liver disease, as evidenced by an only $3.1 \%$ increase in lesion detection in 1175 consecutive patients, resulting in a change in diagnosis in only $1.7 \%$ and a change in follow-up recommendation in $0.85 \%$. [ $9-13$ ]. Therefore, an optimization of image parameters would be useful here.

The aim of this study was to investigate DECT of hypovascular liver metastases in patients with colorectal cancer with a special focus on adjusted window settings (WSs) in addition to the use of low energy data sets.

\section{Materials und Methods}

\section{Patient Population}

Between October 2009 and December 2011, 30 consecutive patients with CRC and LM (17 men, 13 women; mean age 65 years +/- 14 years) underwent dual-energy CT (DECT) for regular staging. The inclusion criterion was an abdominal diameter measured $\leq 35 \mathrm{~cm}$ on the AP or lateral topogram [9].

Liver metastasis was determined by comparison with monoenergetic pre- and follow-up scans (pre 5.3 months \pm 2 (30/30 patients); post 4.8 months \pm 1.9 (30/30 patients). The study was approved by our institutional review board and all patients provided written informed consent before participation.

\section{Imaging Protocol and Scan Parameters}

All CT examinations were obtained using a dual-source multi-detector CT unit (Somatom Definition ${ }^{\mathrm{TM}}$ Dual Source; Siemens Medical Solutions, Forchheim, Germany). This system consists of two X-ray tubes mounted on one gantry at a $90^{\circ}$ angle [14] and two corresponding 64-section detectors. One detector (detector $A$ ) covers a $50-\mathrm{cm}$ field of view and the other detector (detector $B$ ) covers a $26-\mathrm{cm}$ field of view [14]. Patients were positioned supine on the table. Patients were positioned slightly off center to the left to ensure complete coverage of the liver by the smaller field of view of detector B. After intravenous injection of a non-ionic contrast agent (1.5 mL per kilogram of body weight, Xenetix $300^{\mathrm{TM}}$, Guerbet, Sulzbach, Germany), bolus tracking was started in the abdominal aorta at the level of the celiac trunk. Dual-energy datasets were acquired in the portal-venous (bolus tracking and $80 \mathrm{sec}$ ) phase from the dome of the liver to the iliac crest by operating tube A at $140 \mathrm{kVp}$ and a reference value of $96 \mathrm{mAs}$ and tube $B$ at $80 \mathrm{kVp}$ and a reference value of $404 \mathrm{mAs}$. For both tubes, online dose modulation (Care DOSE 4D ${ }^{\mathrm{TM}}$, Siemens Medical Solutions) was used. For the dual-energy $C T$, collimation was set to $14 \times 1.2 \mathrm{~mm}$ on both detectors. For all imaging, the gantry rotation speed was 0.5 seconds.

\section{Post-Processing and Image Reconstruction}

Axial post-contrast images were reconstructed using a section thickness and an increment of $3 \mathrm{~mm}$. Dual-energy CT generates three different series of images: $80 \mathrm{kV}$ images, $140 \mathrm{kV}$ images and weighted-average images, which are based on attenuation information on images obtained from both detectors, using $70 \%$ information from the high $\mathrm{kVp}$ and $30 \%$ from the low $\mathrm{kVp}$ images. Weighted-average images are similar to $120-k V p$ imaging of the abdomen. For post-processing, images were loaded onto a dedicated dual-energy post-processing workstation (syngo MMWP; Siemens Medical Solutions, Forchheim, Germany).

\section{Measurements of Metastases and Image Quality}

Two experienced radiologists read all cases in consensus. On a dedicated workstation (syngo MMWP, Siemens Medical Solutions), 3mm CT images were displayed side-by-side (window setting (WS): 
25/200 HU, 50/200 HU, 75/200 HU, 25/350 HU, 50/350 HU, 75/ $350 \mathrm{HU}, 25 / 500 \mathrm{HU}, 50 / 500 \mathrm{HU}, 75 / 500 \mathrm{HU})$. CT attenuation was determined in 6 regions using regions of interest of $0.2-1.0 \mathrm{~cm}^{2}$ in size: hepatic metastases; normal hepatic parenchyma; aorta at the level of the coeliac trunk; psoas muscle; perihepatic fat; and air in front of the patient. The signal (liver)/noise ratio and liver/LM ratio were calculated (SNR/LLMR). As images could be easily discriminated, radiologists were not blinded as to which image represented the $80 \mathrm{kVp}$ dataset and the virtual $120 \mathrm{kVp}$ dataset. For both CT image sets, the radiologists rated the conspicuity of the LMs on a fivepoint scale: 1: excellent; 2: good; 3: fair; 4: poor; and 5: not interpretable. Both readers reported all LMs separately for the previous best proven and regular (50/350 HU) WSs of the $80 \mathrm{kVp}$ images and the virtual $120 \mathrm{kVp}$ images according to size $(<1 \mathrm{~cm} ; 1-2 \mathrm{~cm}$; $>2 \mathrm{~cm}$ ), total number and number per patient.

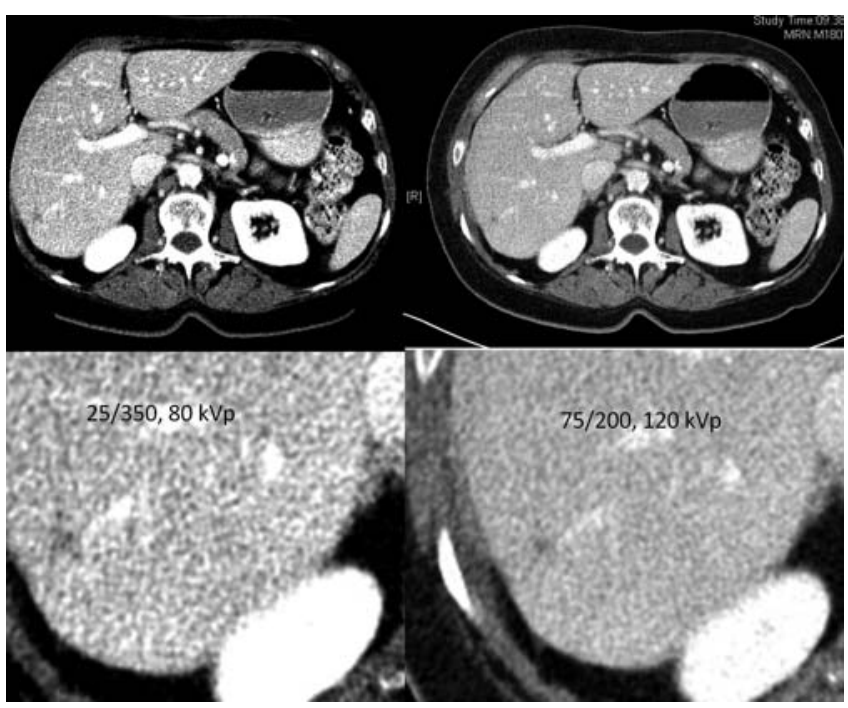

- Fig. 1 Conspicuity of single LM with proven superior WS for $80 \mathrm{kVp}(25 / 350)$ and virtual $120 \mathrm{kVp}$ (75/200) compared to regular abdominal WS (50/350) for each tube voltage.

- Abb. 1 Erkennbarkeit einer einzelnen LM mit verbesserten Fensterwerteinstellungen für 80 kV (25/350) und virtuellen 120 kV (75 200 ) verglichen mit regulären abdominellen Fensterwerteinstellungen (50/350) und jeweiligen Röhrenspannungen.

\section{Statistical Analysis}

CT attenuation, the number of detected LMs and the image quality parameters were tested for differences using the Wilcoxon test for paired samples. The Kruskal-Wallis test was used to investigate statistically significant differences in the qualitative scores. If there was a statistically significant difference among the groups, pairwise comparisons were performed using the Steel-Dwass test [8]. For all studies, a difference with a P-value of less than 0.05 was considered significant. All calculations were performed using statistical software (SPSS, version 21, SPSS Inc., Chicago, USA).

\section{Results}

The best conspicuity of LMs on $80 \mathrm{kVp}$ images was documented with the WS 25/350 HU compared to the best proven WS on virtual $120 \mathrm{kVp}$ images with 75/200 HU (1.2 vs. 2.5; p=0.01) ( $\vee$ Fig. 1). The mean conspicuity of all WSs of the $80 \mathrm{kVp}$ images was 2.6 and significantly better compared to the mean conspicuity of all WSs of the virtual $120 \mathrm{kVp}$ images with $3.9(p<0.05)$. The best mean window width for $80 \mathrm{kVp}$ and virtual $120 \mathrm{kVp}$ images was $350 \mathrm{HU}(1.5 / \mathrm{p}<0.05 ; 3.3 / \mathrm{p}<0.05)$ ( $>$ Table 1$)$.

The best WSs with regard to the conspicuity of LMs (25/350 HU for $80 \mathrm{kVp}$; 75/500 HU for virtual $120 \mathrm{kVp}$ ) were compared to the regular abdominal WSs (50/350 HU for $80 \mathrm{kVp} /$ virtual $120 \mathrm{kVp}$ ) ( $\triangleright$ Table 1, $\vee$ Fig. 2). The highest total number of LMs (218; $p=0.01)$, the mean number of LMs/patient $(7.0 ; p=0.02)$, the mean diameter of LMs/patient $(20 \pm 11 \mathrm{~mm} ; \mathrm{p}<0.01)$, the conspicuity of LMs $(1.2 ; \mathrm{p}<0.01)$ and the total number of $L M s<1 \mathrm{~cm}$ (64; $\mathrm{p}<0.01)$ were better detected with WS 25/350 HU on $80 \mathrm{kVp}$ images. This is in comparison to the best proven WS 75/ $200 \mathrm{HU}$ on virtual $120 \mathrm{kVp}$ images and the regular WS 50/350 $\mathrm{HU}$ on $80 \mathrm{kVp}$ images and virtual $120 \mathrm{kVp}$ images. $80 \mathrm{kVp} 50 /$ $350 \mathrm{HU}$ images, which represent the regular abdominal image parameters, were superior to virtual $120 \mathrm{kVp} 50 / 350 \mathrm{HU}$ with regard to the total number of LMs, the mean number of LMs/patient and the total number of $\mathrm{LMs}<1 \mathrm{~cm}$ ( $\triangleright$ Table 2 ).

The attenuation (HU) of normal liver and aorta as well as the SNR and LLMR differed significantly between $80 \mathrm{kVp}$ images and virtual $120 \mathrm{kVp}$ images (128.1 vs. 93.6; $p<0.05 / 192.8$ vs.131.4; $p<0.05 /$ 10.3 vs. $8.1 ; p<0.05 / 2.8$ vs. $2.1 ; p<0.05)(\triangleright$ Table 3,4$)$. The attenuations of LM, muscle, fat and air were not significantly different.

- Table 1 Conspicuity of LMs depending on window settings (HU) and tube voltage.

- Tab. 1 Erkennbarkeit der LM abhängig von den Fensterwerteinstellungen (HU) und der Röhrenspannung.

\begin{tabular}{|c|c|c|c|c|c|c|}
\hline \multirow{4}{*}{$\begin{array}{l}\text { conspicuity of LMs/each } \\
\text { WS (HU) }\end{array}$} & \multicolumn{3}{|l|}{$80 \mathrm{kVp}$} & \multicolumn{3}{|l|}{$120 \mathrm{kVp}$} \\
\hline & $25 / 200=4.5$ & $25 / 350=1.2$ & $25 / 500=2.8$ & $25 / 200=5.0$ & $25 / 350=3.5$ & $25 / 500=4.5$ \\
\hline & $50 / 200=4.1$ & $50 / 350=1.6$ & $50 / 500=2.7$ & $50 / 200=4.5$ & $50 / 350=3.1$ & $50 / 500=4.6$ \\
\hline & $75 / 200=2.1$ & $75 / 350=1.8$ & $75 / 500=2.8$ & $75 / 200=2.5$ & $75 / 350=3.2$ & $75 / 500=4.6$ \\
\hline $\begin{array}{l}\text { conspicuity of LMs/window } \\
\text { width } 200 / 350 / 500 \mathrm{HU}\end{array}$ & 3.6 & 1.5 & 2.8 & 4 & 3.3 & 4.6 \\
\hline conspicuity of LMs/all WSs & \multicolumn{3}{|l|}{2.6} & \multicolumn{3}{|l|}{3.9} \\
\hline
\end{tabular}



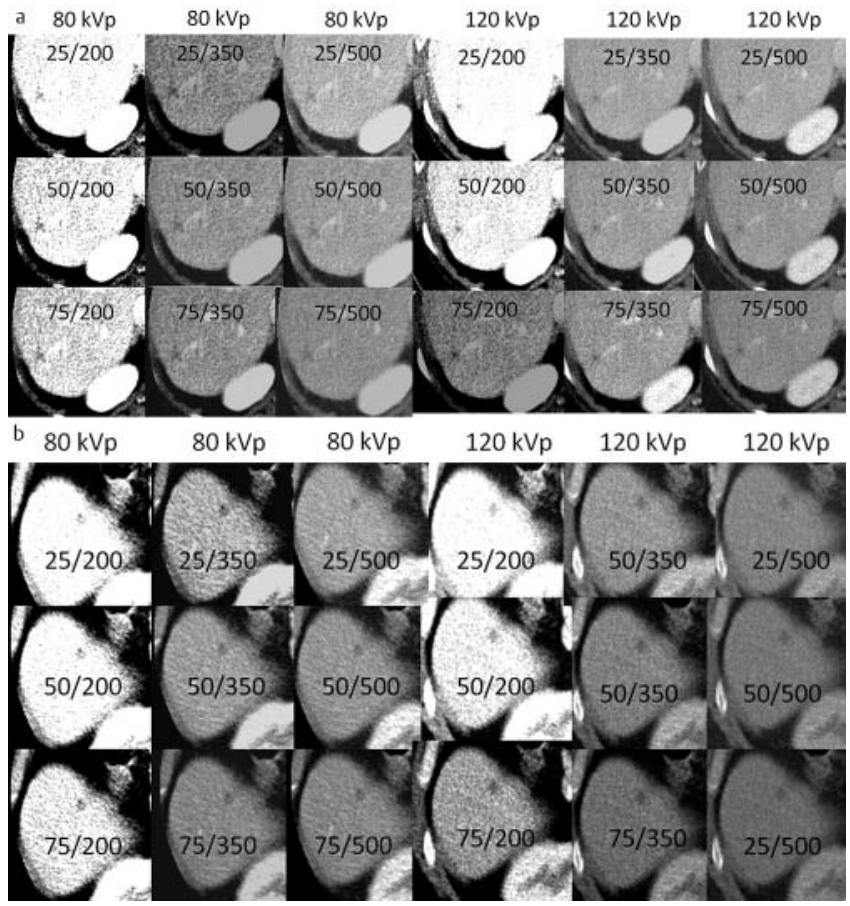

Fig. 2 Conspicuity of single LM with 9 different window settings, each for $80 \mathrm{kVp}$ images and virtual $120 \mathrm{kVp}$ images. Superior image quality was seen with the WS 25/350 for $80 \mathrm{kVp}$ images and the WS 75/200 for virtual $120 \mathrm{kVp}$ images.

- Abb.2 Erkennbarkeit einer einzelnen Lebermetastase mit 9 verschiedenen Fensterwerteinstellungen jeweils für $80 \mathrm{kV}$ - und virtuelle $120 \mathrm{kV}$-Bilddaten. Verbesserte Bildqualität mit WS 25/350 für $80 \mathrm{kV}$ - und WS 75/200 für virtuelle $120 \mathrm{kV}$-Bilddaten.

\section{Discussion}

We demonstrated with our study that hypovascular liver metastases in patients with colorectal cancer could be significantly better detected using low $\mathrm{kVp}$ DECT images compared to $120 \mathrm{kVp}$ virtual DECT images. Robinson et al. concluded in their study (11 patients) that pure $80 \mathrm{kVp}$ data acquired from a dual-source dual-energy MDCT scanner demonstrates greater attenuation differences and improved contrast-to-noise between metastatic disease and normal liver when compared with $120 \mathrm{kVp}$ data [9]. We could show that this increased conspicuity depended not only on a lower tube voltage but also on the selection of special window settings. By comparing $80 \mathrm{kVp}$ images and $120 \mathrm{kVp}$ images, the best image quality was reached with different WSs. For $80 \mathrm{kVp}$, WS $25 / 350$ proved to be superior and for virtual $120 \mathrm{kVp}$, WS $75 / 200$ was superior over the other tested window settings. Finally, we could show that the regular abdominal WS 50/350 was inferior to our evaluated new parameters. Higher total and mean numbers of detected liver metastases especially $<1 \mathrm{~cm}$ were achieved with these adjusted window settings.

Because low kVp DECT increases image noise, contrast enhancement, and soft tissue contrast, Nakaura et al. hypothesized that wide window width display settings would improve the image quality of low $k V p C T$. Their results also suggest that wide window width display settings are optimal for the inspection of low $\mathrm{kVp}$ scans. A wider window width might reduce the contrast in qualitative analysis because it displays a larger CT number range [7]. Our data suggest that low kVp images require a lower window level and width to reach the highest conspicuity.

Chu et al. showed that DECT has the potential to provide added diagnostic value for the evaluation of focal pancreatic tumors. Virtual native images could replace true native images and may reduce radiation dose and the iodine map, while improving the

- Table 2 Comparison of 4 image parameter constellations ( 80 kVp 25/350 HU; 80 kVp 50/350 HU; virtual 120 kVp 75/200 HU; virtual 120 kVp $50 / 350 \mathrm{HU}$ ) with regard to the total number of $\mathrm{LMs}$, mean number of $\mathrm{LMs} /$ patient, mean diameter of $\mathrm{LMs} /$ patient, total number of $\mathrm{LMs}<1 \mathrm{~cm}$, total number of LMs $1-2 \mathrm{~cm}$, total number of LMs $>2 \mathrm{~cm}$, conspicuity of LMs.

- Tab. 2 Vergleich verschiedener Bildparameterkombinationen ( 80 kV 25/350 HU; 80 kV 50/350 HU; virtuell 120 kV 75/200 HU; virtuell 120 kV 50/350 HU) unter Berücksichtigung der Gesamtanzahl der LM, durchschnittlichen Anzahl der LM/Patient, durchschnittlichen Durchmesser der LM/ Patient, Gesamtanzahl der LM $<1 \mathrm{~cm}$, Gesamtanzahl der LM $1-2 \mathrm{~cm}$, Gesamtanzahl der LM $>2 \mathrm{~cm}$ und Erkennbarkeit der LM.

\begin{tabular}{|c|c|c|c|c|c|}
\hline $\begin{array}{l}\text { tube voltage } \\
\text { WS }\end{array}$ & $\begin{array}{l}80 k V p \\
25 / 350 \text { HU }\end{array}$ & $\begin{array}{l}80 \mathrm{kVp} \\
50 / 350 \mathrm{HU}\end{array}$ & $\begin{array}{l}\text { virtual } 120 \mathrm{kVp} \\
75 / 200 \mathrm{HU}\end{array}$ & $\begin{array}{l}\text { virtual } 120 \mathrm{kVp} \\
50 / 350 \mathrm{HU}\end{array}$ & $\begin{array}{l}\text { p-value in multi- } \\
\text { ple comparison }\end{array}$ \\
\hline total number of LMs & 218 & $201^{1}$ & $198^{1}$ & $188^{1}$ & $<0.01^{2}$ \\
\hline mean number of LMs/patient & 7.0 & $6.3^{1}$ & $6.0^{1}$ & $5.3^{1}$ & $<0.02^{2}$ \\
\hline mean diameter of LMs (mm) & $20 \pm 11$ & $23 \pm 10^{1}$ & $24 \pm 7^{1}$ & $26 \pm 6^{1}$ & $<0.01^{2}$ \\
\hline total number of $\mathrm{LMs}<1 \mathrm{~cm}$ & 64 & $53^{1}$ & $45^{1}$ & $40^{1}$ & $<0.01^{2}$ \\
\hline total number of LMs $1-2 \mathrm{~cm}$ & 71 & 68 & 71 & 68 & $<0.8$ \\
\hline total number of $\mathrm{LMs}>2 \mathrm{~cm}$ & 83 & 80 & 82 & 80 & $<0.3$ \\
\hline conspicuity of LMs & 1.2 & $1.6^{1}$ & $2.5^{1}$ & $3.1^{1}$ & $<0.01^{2}$ \\
\hline
\end{tabular}


- Table 3 Attenuation (HU) of LM, normal liver, muscle, fat, air and aorta depending on tube voltage.

- Tab. 3 CT-Dichtewerte (HU) der LM, des gesunden Lebergewebes und von Muskel, Fett, Luft sowie Aorta abhängig von der Röhrenspannung.

\begin{tabular}{|l|l|l|l|}
\hline & $\mathbf{8 0} \mathbf{k V} \mathbf{p}$ & virtual $\mathbf{1 2 0} \mathbf{k V p}$ & $\mathbf{p}$-value \\
\hline LM & $45.4 \pm 10.2$ & $43.2 \pm 11.4$ & 0.2 \\
\hline liver & $128.1 \pm 9.2$ & $93.6 \pm 8.5$ & $<0.05$ \\
\hline muscle & $52.4 \pm 14.7$ & $49.4 \pm 15.9$ & 0.09 \\
\hline fat & $-117.3 \pm 23.1$ & $-104.2 \pm 34.6$ & 0.06 \\
\hline air & $-1012.4 \pm 132.7$ & $-1000.5 \pm 103.5$ & 0.5 \\
\hline aorta & $192.8 \pm 23.1$ & $131.4 \pm 26.3$ & $<0.05$ \\
\hline
\end{tabular}

- Table 4 Background noise (BN), signal (liver)/noise ratio (SNR) and liver/LM ratio depending on tube voltage.

- Tab. 4 Hintergrundrauschen (BN), Signal (Leber)/Rausch-Verhältnis (SNR) und Leber/LM-Verhältnis (LLMR) abhängig von der Röhrenspannung.

\begin{tabular}{|l|r|r|l|}
\hline & $\mathbf{8 0} \mathbf{~ k V}$ & virtual 120 $\mathbf{~ k V}$ & $\mathbf{p}$-value \\
\hline BN & $12.4 \pm 4.3$ & $11.5 \pm 3.2$ & 0.4 \\
\hline SNR & $10.3 \pm 2.6$ & $8.1 \pm 3.1$ & $<0.05$ \\
\hline LLMR & $2.8 \pm 0.8$ & $2.1 \pm 0.5$ & $<0.05$ \\
\hline
\end{tabular}

differentiation between cystic or solid nature of lesions and improving lesion conspicuity compared with simulated weighted $120 \mathrm{kVp}$ images. In their study, the differences in CNR between the images with a weighting factor of 0.3 and the images with a weighting factor of 0.5 or 0.7 were statistically significant (different?) among the cystic lesions and solid hypovascular tumors (p: 0.05) [15]. Therefore, this might be another important parameter in addition to WS with influence on the image quality and conspicuity of hypovascular lesions.

Our study has some limitations. No histological samples of liver metastases were available. However, with the help of pre- and follow-up scans, we were able to perform reliable differentiation in our opinion. Non-cystic lesions with a size increase or decrease, completely new lesions or lesions that were unrecognizable on follow-up scans were rated as LM. The evaluation of LM recognizability was a subjective process, which was offset by a consensus decision of two experienced radiologists. Although a certain body circumference was regarded for the inclusion of patients, we did not consider this parameter in the statistical analysis. The most notable disadvantage of low-voltage CT is the potential for increased image noise $(4,5,7,9,17)$ resulting from the lower tube energy, which results in unacceptable images in large patients. Beyond a certain patient size, the benefit of increased contrast and increased contrast-to-noise ratio (CNR) at $80 \mathrm{kV}$ is offset by the increased noise and beam-hardening artifacts, thus making abdominal $80 \mathrm{kV}$ single-source and dual-energy $\mathrm{CT}$ (using $80 \mathrm{kV}$ in the lower energy tube) inadvisable $[16,17]$.

In conclusion, our study demonstrates that DECT is a promising tool for detecting hypovascular liver metastases. The diagnostic value of low $\mathrm{kVp}$ image data can be significantly increased by using special window settings.

\section{CLINICAL RELEVANCE}

- DECT is a promising tool for detecting hypovascular liver metastases.

- The diagnostic value of low kVp image data can be significantly increased by using special window settings.

- The use of low kVp images leads to reduced radiation exposure.

\section{References}

[1] Altenbernd J, Heusner TA, Ringelstein A et al. Dual-energy-CT of hypervascular liver lesions in patients with HCC: investigation of image quality and sensitivity. Eur Radiol 2011; 21: 738 - 743

[2] Fletcher JG, Takahashi N, Hartman R et al. Dual-energy and dual-source $\mathrm{CT}$ : is there a role in the abdomen and pelvis? Radiol Clin North Am 2009; 47: $41-57$

[3] Graser A, Johnson TR, Chandarana $\mathrm{H}$ et al. Dual energy CT: preliminary observations and potential clinical applications in the abdomen. Eur Radiol 2009; 19: 13-23

[4] Yeh BM, Shepherd JA, Wang Z] et al. Dual-energy and low-kVp CT in the abdomen. Am J Roentgenol 2009; 193: 47-54

[5] Schindera ST, Nelson RC, Mukundan S Jr et al. Hypervascular liver tumors: low tube voltage, high tube current multi-detector row CT for enhanced detection-phantom study. Radiology 2008; 246: 125-132

[6] Macari M, Spieler B, Kim D et al. Dual-source dual-energy MDCT of pancreatic adenocarcinoma: initial observations with data generated at $80 \mathrm{kVp}$ and at simulated weighted-average $120 \mathrm{kVp}$. Am J Roentgenol 2010; 194: W27-W32

[7] Nakaura T, Awai K, Oda S et al. Low-kilovoltage, high-tube-current MDCT of liver in thin adults: pilot study evaluating radiation dose, image quality, and display settings. Am J Roentgenol 2011; 196: 1332 -1338

[8] Nakayama Y, Awai K, Funama Y et al. Abdominal CT with low tube voltage: preliminary observations about radiation dose, contrast enhancement, image quality, and noise. Radiology 2005; 237: 945-951

[9] Robinson E, Babb J, Chandarana $\mathrm{H}$ et al. Dual source dual energy MDCT: comparison of $80 \mathrm{kVp}$ and weighted average $120 \mathrm{kVp}$ data for conspicuity of hypo-vascular liver metastases. Invest Radiol 2010; 45: 413-418

[10] Brink JA. Liver window settings at hepatic CT: added value or marginal cost? Radiology 1999; 210: $593-594$

[11] Maguire WM, Herman PG, Khan A et al. Comparison of fixed and adjustable window width and level settings in the $\mathrm{CT}$ evaluation of diffuse lung disease. J Comput Assist Tomogr 1993; 17: 847-852

[12] Pomerantz SM, White CS, Krebs TL et al. Liver and bone window settings for soft-copy interpretation of chest and abdominal CT. Am J Roentgenol 2000; 174: $311-314$

[13] Sahi K, Jackson S, Wiebe E et al. The value of "liver windows" settings in the detection of small renal cell carcinomas on unenhanced computed tomography. Can Assoc Radiol J 2014; 65: 71-76

[14] Flohr TG, McCollough CH, Bruder $\mathrm{H}$ et al. First performance evaluation of a dual-source CT (DSCT) system. Eur Radiol 2006; 16: 256-268

[15] Chu AJ, Lee JM, Lee Y] et al. Dual-source, dual-energy multidetector CT for the evaluation of pancreatic tumours. Br J Radiol 2012; 85: e891 - e898

[16] Guimaraes LS, Fletcher JG, Harmsen WS et al. Appropriate patient selection at abdominal dual-energy CT using $80 \mathrm{kV}$ : relationship between patient size, image noise, and image quality. Radiology 2010; 257: 732 742 